\title{
Cell penetrating peptides can exert biological activity: a review
}

\author{
Jamie Brugnano ${ }^{1}$, Brian C. Ward ${ }^{1,2}$ and \\ Alyssa Panitch ${ }^{1, *}$ \\ ${ }^{1}$ Weldon School of Biomedical Engineering, Purdue \\ University, 206 South Martin Jischke Drive, West \\ Lafayette, IN 47907, USA \\ ${ }^{2}$ Indiana School of Medicine, 340 West 10th Street, \\ Indianapolis, IN 46202-3082, USA \\ * Corresponding author \\ e-mail: apanitch@purdue.edu
}

\begin{abstract}
Cell penetrating peptides (CPPs) have been successful in delivering cargo into many different cell types and are an important alternative to other methods of permeation that might damage the integrity of the cell membrane. The traditional view of CPPs is that they are inert molecules that can be successfully used to deliver many cargos intracellularly. The goal of this review is to challenge this traditional understanding of CPPs. Recent literature has demonstrated that CPPs themselves can convey biological activity, including the alteration of gene expression and inhibition of protein kinases and proteolytic activity. Further characterization of CPPs is required to determine the extent of this activity. Research into the use of CPPs for intracellular delivery should continue with investigators being aware of these recent results.
\end{abstract}

Keywords: biological activity; cell penetrating peptides; gene expression; protein kinase; protein transduction domains; proteolytic activity.

\section{Introduction}

Cell penetrating peptides (CPPs) have successfully delivered a variety of cargo to the interior of cells, including peptides, antibodies (1, 2), nanoparticles (3), oligonucleotides (4), siRNA (5), adenoviruses (6), and DNA for more than two decades $(7,8)$. CPPs circumvent the need for permeation methods such as electroporation and chemical transfection that might damage the cell membrane. CPPs, which have also been referred to as protein transduction domains, are typically defined as less than 30 amino acids in length, are amphipathic, contain a net positive charge, and most importantly, can deliver cargo across the plasma cell membrane.
Several hydrophobic CPP sequences have also been identified.

The most widely used CPP for cargo delivery is the human immunodeficiency virus-transactivator of transcription (HIVTat or simply, Tat). The ability of Tat to cross the cell membrane was discovered in 1988 by two separate research groups $(9,10)$. Nine years later, Vives et al. identified the minimum amino acid sequence required for Tat to transduce the cell membrane (11). Antennapedia (Antp), which is a 16amino acid CPP from a Drosophila transcription factor, was the first CPP used to demonstrate in vitro intracellular protein delivery (12). In 1999, Schwarze et al. reported the ability of Tat to deliver cargo in vivo (13). Once the potential of CPPs was discovered, investigators focused on expanding the repertoire of CPPs in an effort to maximize transduction efficiency of various cargos.

Uptake of CPPs is traditionally confirmed with visualization of fluorescently labeled peptides within cells, either with microscopy or fluorescence-activated cell sorting (FACs). Transduction can only be confirmed once cells have been treated with proteases and a fluorescent quenching technique to remove any residual peptide binding to the cell surface (14). Cells must be alive during visualization because the process of fixation has been shown to alter the distribution of CPPs within the cell (14). Although microscopy and FACs have been widely used within the literature to confirm CPP transduction, two disadvantages have been identified with these systems. First, the utilization of FACs or microscopy significantly overestimates the amount of peptide that permeates the cell membrane (15). Both FACS and microscopy are unable to differentiate between peptide that is localized within endocytotic vesicles and peptide that has exited into the cell cytoplasm. Escape from endocytotic vesicles is often required for the delivered cargo to exert its effect. To overcome this limitation, investigators have turned to functional assays that can confirm the transduction of peptides. However, functional assays often do not allow for the quantification of CPP efficiency. Phenotypic assays that utilize the Cre-LoxP system have recently been used to quantify the amount of CPP that effectively transduces into the cell cytoplasm (15). The second problem with the use of fluorophores is that they can change the mechanism of translocation of CPPs by affecting the structure (conformation or flexibility) of the CPPs, which in turn could affect uptake, toxicity, or intracellular distribution $(16,17)$.

The mechanism by which CPPs are able to translocate into the cell cytoplasm has been an issue of debate since CPPs 
were discovered. It is generally agreed that CPP uptake occurs via non-receptor mediated endocytosis. However, clarifying whether it occurs through clathrin, caveolae, or macropinocytosis is still highly controversial. The specific pathway of endocytosis is dependent upon several factors including the amino acid sequence of the CPP, the cargo being delivered, the extracellular peptide concentration, and the proteoglycan concentration on the cell surface $(18,19)$. Recently, Gump et al. investigated the effect of surface glycosaminoglycans and sialic acid on the transduction of Tat (15). A deficiency in surface sialic acids and glycosaminoglycans significantly reduced Tat uptake but did not entirely inhibit transduction. Interestingly, the enzymatic removal of all cell surface proteins completely inhibited the uptake of Tat (15). The identity of these crucial cell surface proteins has yet to be discovered, and the importance of these proteins in the uptake of other CPPs has not yet been explored.

Although the mechanism of transduction of CPPs is still highly controversial, it is accepted that CPPs can successfully deliver cargo, such as bioactive peptides, into a wide variety of cells. Several investigators have been interested in delivering pro-apoptotic peptides as a means of inhibiting the growth of cancer cells (20-22). Others have used CPPs to inhibit kinases crucial for the proliferation of cancer cells $(23,24)$. Table 1 shows a list of known CPPs. The list is by no means comprehensive, but gives an idea of the variety and number of CPPs that exist. The more well-known CPPs (e.g., Tat and Antp) have several references where the CPP was used to successfully deliver cargo into cell. The references cited within the table were an attempt at citing those articles that first published the ability of each CPP to deliver cargo within cells. It is important to note that some of the cited papers in Table 1 were published before discovering the effects of cell fixation and the importance of using enzymes and a fluorescent quenching technique to visualize CPPs within the cell.

Traditionally, CPPs have been regarded as inert molecules that are void of biological activity. This statement is supported by the multitude of publications that simply add a cell-penetrating domain to the cargo of interest to achieve intracellular delivery. However, an important issue regarding CPPs that is often overlooked within the literature is that CPPs themselves can convey biological activity. Not only have CPPs demonstrated differences in effectiveness between cell lines $(22,61)$, but also CPPs have been shown to affect protein function and gene expression. This review will highlight recent research that has found CPPs to be biologically active. As we proceed forward with CPP research, it is crucial to be aware of the potential effects that CPPs themselves might have.

\section{Body of Literature Review}

Since the discovery that CPPs can be used to deliver cargo across the cell membrane, delivery of a variety of compounds including bioactive peptides, proteins, DNA, siRNA and particles, has been studied. The majority of these studies validate delivery of the bioactive compound by probing for the anticipated biological activity. However, until recently, few studies have investigated whether the CPPs themselves might convey some unintended or undesirable biological activity. Within the past few years, studies have shown that CPPs can inhibit proteolytic activity (62-65), modulate the metabolic profile of cells (66), alter gene expression (67) and inhibit kinase activity (31). The biological activity is clearly related to the CPP sequence and some CPPs show only marginal unintended biological activity.

As we strive to utilize large molecules and other entities that have traditionally been difficult to transport across the cell membrane, we must proceed with caution. It is crucial that not only the intended biological outcome be probed, but also unintended activity. In most cases, only moderate unintended activity can be seen as in the case of CPP YARAAARQARA (47) and its inhibition of kinase function (31); but in other cases, such as the use of the modified heparin-binding peptide, WLRRIKAWLRRIKA used to deliver peptide kinase inhibitors, wide scale nonspecific kinase activity is obtained, thus effecting the measured biological outcomes (31). Not only can this unintended biological activity lead to side effects for the therapeutic application, but it could also convey misleading information about cell behavior, cell signaling, and other biological activities.

Recent evidence suggests that in some cases, CPPs can inhibit protease functions. Research on peptides rich in basic amino acids shows that they are potent inhibitors of proprotein convertases (PCs) (64). The PCs are calcium-dependant subtilisin/kexin-related serine endopeptidases, which are central to several cellular functions including activation of proteins in the secretory pathway. Through screening of both Land D-hexapeptide libraries, Fugere et al. examined the inhibition of PC7 and PC5/6 specifically. Overall, they found a strong preference for basic amino acids in each of the six positions of the hexapeptide. In addition, there was a strong preference for tryptophan (4th most probable amino acid) at positions 5 and 6. Quoting directly from the conclusions, 'We believe that certain poly-arginine peptides, including nonaD-arginine, are interesting compounds for the blockade of PC activity in therapeutic strategies, but only if the treatment of the pathological condition requires the inhibition of several PCs of the constitutive secretory pathway (i.e., furin, PACE4, PC5/6 and PC7).' These findings are consistent with polyargine inhibition of Furin, a related endoprotease (62).

Interestingly, Kloss et al. specifically studied the effects of the CPP octa-arginine on proteasome activity (65). This careful study showed that increasing polyarginine chain length from four residues to eight residues increased the inhibitory activity. Although one can assume that because the polyarginines are exposed to many different proteases within the cell they will be degraded rapidly, several studies demonstrating that polyarginines and polybasic amino acids are able to inhibit many intracellular proteases suggest that the peptides might survive for extended periods of time within the cell and could have unintended activities. The consequence of this strong proteasome inhibition discovered by Kloss et 
Table 1 Table of known CPP sequences.

\begin{tabular}{|c|c|c|}
\hline $\mathrm{CPP}$ sequence & Name & References \\
\hline YGRKKRRQRRR & Tat & $(25)^{a} /(26)^{b}$ \\
\hline KCFQWQRNMRKVRGPPVSCIKR & Human lactoferrin & (27) \\
\hline KLWMRWYSPTTRRYG & IVV Peptide Library ${ }^{\mathrm{c}}$ & $(28)$ \\
\hline DSLKSYWYLQKFSWR & IVV Peptide Library ${ }^{\mathrm{c}}$ & (28) \\
\hline CSIPPEVKFNPFVYLI & $\mathrm{C} 105 \mathrm{Y}$ & (29) \\
\hline SDLWEMMMVSLACQY & Pep7 & $(30)$ \\
\hline KAFAKLAARLYR & Heparin binding CPP & $(31)$ \\
\hline FAKLAARLYR & Heparin binding CPP & $(31)$ \\
\hline GWTLNSAGYLLGKINLKALAALAKKIL & Transportan (TP) & $(32)$ \\
\hline ACSSSPSKHCG & TD1 & (33) \\
\hline RGGRLSYSRRRFSTSTGRA & SynB1 & (34) \\
\hline KETWWETWWTEWSQPKKKRKV & Pep1/Chariot & $(35)$ \\
\hline RRRRRRRRR & R9 & $(36)$ \\
\hline AGYLLGKINLKALAALAKKIL & TP10 & $(37)$ \\
\hline RQIKIWFQNRRMKWKK & Penetratin (Antp) ${ }^{\mathrm{d}}$ & $(38)$ \\
\hline GLWRALWRLLRSLWRLLWKA & CADY & (39) \\
\hline LLIILRRRIRKQAHAHSK & pVEC & $(40)$ \\
\hline APKRKSGVSK & Polyomavirus Vp1 & (41) \\
\hline WLRRIKAWLRRIKA & Heparin binding CPP & $(42)$ \\
\hline PFVYLI & PVF & (22) \\
\hline *Sequence too long for table & HSV VP22 & (43) \\
\hline VTVLALGALAGVGVG & Integrin $\beta 3$ & (44) \\
\hline AAVALLPAVLLALLAP & FGF & $(45)$ \\
\hline KLALKLALKALKAALKLA & MAP & (46) \\
\hline YARAAARQARA & Optimized Tat & $(47)$ \\
\hline$(\mathrm{KKK})_{n}$ & Poly(Lysine) & (48) \\
\hline LGTYTQDFNKFHTFPQTAIGVGAP & Human hCT & $(49,50) /(51)^{\mathrm{e}}$ \\
\hline DPKGDPKGVTVTVTVTVTGKGDPKPD & VT5 & $(52)$ \\
\hline ASMWERVKSIIKSSLAAASNI & FHV $\gamma_{1}$ peptide & (53) \\
\hline IGVAASGISGLSALFEGFGF & FHV peptide & $(16)$ \\
\hline SRYDDSVPRYHAVRIRKEEREIKDEK & Integrin peptide & (16) \\
\hline RRIRPRPPRLPRPRPRPLPFPRPG & $\mathrm{Bac}$ & (54) \\
\hline LEAEKERRKSGLSS & Integrin Peptide & (16) \\
\hline RKKRRRESRKKRRRES & Vectocell ${ }^{\circledR}$ DPV3 & $(55)$ \\
\hline GRPRESGKKRKRKRLKP & Vectocell ${ }^{\circledR}$ DPV6 & $(55)$ \\
\hline GKRKKKGKLGKKRDP & Vectocell ${ }^{\circledR}$ DPV7 & $(55)$ \\
\hline VKRGLKLRHVRPRVTRMDV & Vectocell ${ }^{\circledR}$ DPV 1047 & $(55)$ \\
\hline SRRARRSPRHLGSG & Vectocell ${ }^{\circledR}$ DPV10 & $(55)$ \\
\hline LRRERQSRLRRERQSR & Vectocell ${ }^{\circledR}$ DPV15 & $(55)$ \\
\hline GALFLGFLGAAGSTMGAWSQPKSKRKV & MPG & $(56)$ \\
\hline MVTVLFRRLRIRRASGPPRVRV & M918 & $(57)$ \\
\hline AGYLLGKINLKALAALAKKIL & TP10 & $(37)$ \\
\hline LIRLWSHLIHIWFQNRRLKWKKK & EB-1 & $(58)$ \\
\hline MVKSKIGSWILVLFVAMWSDVGLCKKRPKP & Bovine PrP & $(58)$ \\
\hline ALWKTLLKKVLKAPKKKRKV & S413-PV & $(59)$ \\
\hline VRLPPPVLRPPPVLRPPP & PolyP & (60) \\
\hline
\end{tabular}

${ }^{a}$ First time TAT was used to deliver cargo; but CPP sequence was longer than the 11 amino acid sequence commonly used today.

${ }^{\text {bTAT }}$ synthesized with d-amino acids reported to transduce comparably.

${ }^{\mathrm{C}} \mathrm{CPP}$ itself has only been tested for transduction activity; the ability to transduce cargo has not yet been analyzed.

${ }^{\mathrm{d} P e n e t r a t i n}$ and Antp are names used to describe the same sequence.

${ }^{\mathrm{e} h C T}$ analogs with improved metabolic stability.

al. might be a decrease in both ubiquitin-related and ubiquitin-independent proteolytic activity. General intracellular protease inhibition can affect several cellular activities including cell growth and metabolism.

Further evidence that polyarginines might have properties in addition to their ability to carry cargo across the cell membrane comes from a study by Horn et al. (63). They found that arginine-rich peptides inhibit cathepsin C. They also used a peptide library to screen for inhibitors. Peptide sequences containing a minimum of three sequential arginine residues showed $\mathrm{IC}_{50}$ values in the tens of micromolar range.

Additionally, Delaroche et al. found that the arginine- and tryptophan-rich CPPs (R/W)16 (RRWRRWWRRWWRRWRR), (R/W)9 (RRWWRRWRR), and R9 (RRRRRRRRR) 
Table 2 Summary of biological activity of CPPs.

\begin{tabular}{lccccc}
\hline CPP & \multicolumn{3}{c}{ Unintended biological activity } & & \\
\cline { 2 - 6 } & $\begin{array}{c}\text { Proteolytic } \\
\text { inhibition }\end{array}$ & $\begin{array}{c}\text { Kinase } \\
\text { inhibition }\end{array}$ & $\begin{array}{c}\text { Gene } \\
\text { expression }\end{array}$ & $\begin{array}{c}\text { Receptor } \\
\text { recycling }\end{array}$ & $\begin{array}{c}\text { Metabolic } \\
\text { profile }\end{array}$ \\
\hline pTAT & $\mathrm{X}$ & $\mathrm{X}$ & $\mathrm{X}$ & $\mathrm{X}$ & $\mathrm{X}$ \\
pArg & & $\mathrm{X}$ & $\mathrm{X}$ & $\mathrm{X}$ \\
pAntp & & $\mathrm{X}$ & $\mathrm{X}$ \\
MAP & & $\mathrm{X}$ & $\mathrm{X}$ \\
TP & & $\mathrm{X}$ & & \\
FAK & & $\mathrm{X}$ & & \\
KAFAF & $\mathrm{X}$ & & \\
WLRRIKA & & & \\
\hline
\end{tabular}

affected the polymerization of actin in vitro (68). Through calorimetry and NMR, all three CPPs were found to directly bind $\mathrm{G}$-actin, with $(\mathrm{R} / \mathrm{W}) 16$ showing the highest affinity $\left(K_{\mathrm{d}}=10 \mu \mathrm{M}\right)$. Interestingly, all three CPPs induced morphological changes through stress fiber reorganization that was evident in malignant fibroblasts but not in normal fibroblasts. The change in stress fiber organization affected the rate of motility and the wound healing ability of the malignant fibroblasts (68).

Other studies have shown that CPPs can affect cargo function. For example, Niesner et al. found that the addition of Tat to antibody fragments was deleterious to antibody function (26). ScFV(L19) is a human antibody fragment to the ED-B domain of fibronectin, a marker of angiogenesis that has tumor targeting properties. Addition of TAT to ScFV(L19) increased the ability of the antibody to transduce into cells, but inhibited the tumor targeting ability of the antibody. After $24 \mathrm{~h}$, mice injected with SCFV(L19) accumulated $8 \%$ of the injected dose at the tumor site, whereas only $0.5 \%$ was found at the site of the tumor with the addition of Tat CPP (26).

Additional evidence that more needs to be learned about the biological activity that some CPPs themselves convey comes from work by Kilk et al. (66). Using a technique long used in drug development, they examined the metabolic profile of Chinese hamster ovary $(\mathrm{CHO})$ cells before and after treatment with each of five known cell-penetrating peptides. The five peptides examined include Tat, Antp, transportin (TP), MAP and R9 (see Table 1 for sequences). The investigators used metabolic profiling as a method to determine the safety and toxicity of drugs. Initial studies looked at untargeted profiling, or profiling of a broad panel of metabolites to determine if there were varying unknown biological activities among the different cell-penetrating peptides. The study demonstrated that the long-term effects on cellular homeostasis of pTat, pAntp and R9 were likely to be minimal; however, TP might have a greater impact. Although it is not yet clear what the long-term significance of the profiling data is with respect to the efficacy of CPPs as carriers, the data clearly show that the five different cell-penetrating peptides have different biological impact.

Not only can CPPs affect protease activity and the metabolic state of cells, but they might also create more global changes. Several studies have shown that gene expression can be affected by CPPs alone. In vivo studies in mouse lung demonstrated a downregulation of p38MAPK when animals were treated with Tat and Antp CPPs. Surprisingly, conjugation of these CPPs to p38MAPK-siRNA did not further attenuate p38 MAPK gene expression (69); it is possible that other genes were also affected, but only p38 MAPK was examined in this study. Waldeck et al. showed that CPPs affect gene expression in HeLa cells cultured in vitro (70). Four CPPs were examined including the Tat and ANTp peptides studied by Kilk et al. (66) and two additional TP peptides, KKMTRQTWWHRIKHKC and KMTRQTFWHRIKHKC. As determined by a two-fold up or downregulation, they found that the Antp affected the expression of 19 genes, the HIV-1 Tat peptide affected the expression of 18 genes and the two TP peptides affected seven and eight genes respectively. Further confirming that CPPs can affect gene expression, Kuo et al. examined the global gene expression of U-937 macrophages treated with octaarginine (67). In this case 4386 genes were differentially regulated 0.5 and $4 \mathrm{~h}$ after exposure to $10 \mu \mathrm{M}$ peptide. Although it is unclear how the altered gene expression will ultimately affect the safety and efficacy of drugs that utilize these CPPs for entry into cells, it is clear that the consideration of off target activity must be taken into account when analyzing the results of studies utilizing all CPPs.

Induction of cell surface receptor internalization has also been attributed to CPPs. In a thorough study by Fotin-Mleczek et al., pANT, pTat and R8 were all found to induce TNFR1 and TNFR2 internalization. Internalization occurred primarily through clatherin-coated vesicles (71). Decrease in TNFR membrane concentration was as great as $40 \%$.

Our own work shows that CPPs can also inhibit kinases (31). Four CPPs conjugated to a peptide known to inhibit MK2 were evaluated for specificity to MK2 by comparing inhibition of up to 40 different kinases. We found that three CPPs derived from natural heparin-binding peptides, conjugated to an MK2 inhibitor peptide, showed not only varying $\mathrm{IC}_{50}$ values, but also varying MK2 specificity. A synthetic and optimized version of Tat, with the amino acid sequence YARAAARQARA, conveyed the greatest specificity to our MK2 inhibitor peptide. The YARAAARARA CPP has less positive charge than other peptides tested and also, in general, has a lower hydrophobic content. Thus, it is possible 
that a combination of positive charge and hydrophobic content is crucial in conveying nonspecific biological activity.

In unpublished results we found that CPPs themselves affected the activity of the MK2 kinase. The Omnia ${ }^{\circledR}$ Kinase Assay for MAPKAP-K2 kit (Invitrogen) was used to determine the reaction velocity for MK2 in the presence and absence of Tat, synthetic Tat variant (YARAAARQARA) and a novel CPP (WLRRIKAWLRRIKA). The kit contains a proprietary reaction buffer to which the following were added (final concentrations are given): $1 \mathrm{~mm}$ ATP, $0.2 \mathrm{~mm}$ DTT, $10 \mu \mathrm{M}$ MAPKAP-K2 Sox-modified peptide substrate, $5 \mathrm{ng} \mathrm{MK} 2$, and the peptide inhibitor of interest (final volume of $50 \mu \mathrm{l}$ ). Human MK2 was purchased from Millipore. The reactions were performed at $30^{\circ} \mathrm{C}$ in the wells of a lowprotein-binding 96-well plate provided with the kit, and fluorescence readings $($ excitation $=360 \mathrm{~nm}$, emission $=485 \mathrm{~nm}$ ) were taken every $30 \mathrm{~s}$ for $20 \mathrm{~min}$ using a SpectraMax M5 Spectrophotometer (Molecular Devices, Sunnyvale, CA, USA). Reaction velocity was determined for each reaction well from the slope of a plot of relative fluorescence units vs. time. Each inhibitor peptide was tested at four concentrations, 12.5, 25, 50 and $100 \mu \mathrm{M}$, in triplicate. The activity of the novel CPP WLRRIKAWLRRIKA was $83 \pm 4 \%$ greater than the known MK2 inhibitor peptide, KKKALNRQLGVAA (72). Tat also inhibited MK2, but to a lesser degree; it was found to inhibit MK2 with $44 \pm 17 \%$ less activity than the known inhibitor peptide. At the same time, the synthetic Tat peptide variant YARAAARQARA was found to be a poor inhibitor of $\mathrm{MK} 2$ and had an $\mathrm{IC}_{50}$ value greater than $3 \mathrm{~mm}$.

Taken together these studies show that many of the polycationic CPPs can have a variety of unintended biological activities. These range from altering a wide variety of protein functions to affecting gene expression. Importantly, as detailed above, many of the CPPs affect intracrine function. The CPPs are taken up by the cells and then alter cellular function owing to their intracellular activity. In our own studies, broad kinase inhibition led to increased cell death (31). Kloss et al. showed that there was an increase in high molecular mass ubiquinated protein accumulation in HeLa cells treated with polyarginine CPPs (65). Indeed, many of the unintended biological activities recently seen when treating cells with CPPs are probably owing to altered intracrine function. In future studies, investigators must be aware that these additional biological activities could be affecting the results obtained.

Less well studied with regard to nonspecific activities are the hydrophobic CPPs. Owing to the range of nonspecificity seen with some of the cationic CPPs, additional studies are warranted for all CPPs.

\section{Expert opinion}

CPPs have great potential to positively impact both our knowledge of biology and human health. Delivery of otherwise membrane impermeable cargo allows researchers to evaluate the cellular effects of small peptide drugs and pro- teins, to evaluate the knockdown of proteins through siRNA delivery and to evaluate the overexpression of proteins through gene delivery. Nanoparticles can be introduced into cells for imaging, or drug delivery. A recent search for 'cell penetrating peptide' in Google Scholar resulted in over 45000 hits, which shows the interest in and impact of this technology.

Although the possibilities for cell-penetrating peptides are great, researchers need to proceed with caution. The expected biological activity of a molecule might be masked or impacted by off-target biological activities. For example, FotinMleczek et al. used CPPs to deliver a proapoptotic peptide; however, they found that when the proapoptotic peptide was delivered using electroporation it was significantly more active than when delivered with CPPs (71). Further investigation led to the realization that the CPPs were causing $\mathrm{TNF} \alpha$ receptor recycling, which decreased apoptosis. Thus, the activity of the CPP itself opposed that of the cargo it was delivering. Only careful analysis of the data and additional investigation identified this opposing behavior and, thus, helped further our understanding of CPPs.

Once the biological activity of the CPP-therapeutic has been well characterized there is vast potential for the use of these peptides for therapeutic benefit. Peptide drugs utilizing CPPs are in clinical and preclinical trials in the area of tumor reduction utilizing a fragment of azurin (73) and for inhibition of dermal scarring utilizing a fragment of the small heat shock-like protein HSP20 (74). In the case of dermal scarring the peptide has completed phase II clinical trails for dermal scarring and keloid revisions and trial results are pending. The positive results, thus far, for these therapeutics further suggests that CPPs have vast potential in human health.

\section{Outlook}

The outlook for CPPs is bright. CPPs have provided the ability to deliver compounds, which were previously excluded from the cell, across the cell membrane. This, in turn, has allowed researchers to ask biological questions that were previously difficult to query. Equally as importantly, CPPs have opened the door to the delivery of proteins, peptides, RNA and DNA into cells in vivo for the treatment of disease.

\section{Highlights}

- CPPs can have unexpected biological activity.

- Kinase activity can be affected by the CPP itself.

- Some CPPs can affect proteolytic activity.

- Gene expression is altered by polycationic CPPs.

- CPPs can affect cargo function.

- CPPs can have intracrine effects.

- Future CPP work needs to continue probing for unexpected biological activity which most probably results from altered intracrine function. 


\section{Acknowledgements}

This work was funded, in part, by a grant (K25HL074968) from the National Institutes of Health. J.B. is funded through a predoctoral fellowship from the National Science Foundation and B.W. was supported in part by a Purdue Research Foundation Fellowship.

\section{References}

1. Kameyama S, Horie M, Kikuchi T, Omura T, Takeuchi T, Nakase I, Sugiura Y, Futaki, S. Effects of cell-permeating peptide binding on the distribution of ${ }^{125}$ I-labeled Fab fragment in rats. Bioconjug Chem 2006; 17: 597-602.

2. Kameyama S, Okada R, Kikuchi T, Omura T, Nakase I, Takeuchi T, Sugiura Y, Futaki S. Distribution of immunoglobulin Fab fragment conjugated with HIV-1 REV peptide following intravenous administration in rats. Mol Pharm 2006; 3: 174-80.

3. Josephson L, Tung CH, Moore A, Weissleder R. High-efficiency intracellular magnetic labeling with novel superparamagnetic-Tat peptide conjugates. Bioconjug Chem 1999; 10: 186-91.

4. Abes R, Arzumanov AA, Moulton HM, Abes S, Ivanova GD, Iversen PL, Gait MJ, Lebleu B. Cell-penetrating-peptide-based delivery of oligonucleotides: an overview. Biochem Soc $\mathrm{T}$ 2007; 35: 775-9.

5. Eguchi A, Dowdy SF. siRNA delivery using peptide transduction domains. Trends Pharmacol Sci 2009; 30: 341-5.

6. Eto Y, Yoshioka Y, Asavatanabodee R, Kida S, Maeda M, Mukai Y, Mizuguchi H, Kawasaki K, Okada N, Nakagawa S. Transduction of adenovirus vectors modified with cell-penetrating peptides. Peptides 2009; 30: 1548-52.

7. Sawant R, Torchilin V. Intracellular transduction using cell-penetrating peptides. Mol Biosyst 2010; 6: 628-40.

8. Dietz GP, Bahr M. Delivery of bioactive molecules into the cell: the Trojan horse approach. Mol Cell Neurosci 2004; 27: 85-131.

9. Green M, Loewenstein PM. Autonomous functional domains of chemically synthesized human immunodeficiency virus tat trans-activator protein. Cell 1988; 55: 1179-88.

10. Frankel AD, Pabo CO. Cellular uptake of the tat protein from human immunodeficiency virus. Cell 1988; 55: 1189-93.

11. Vives E, Brodin P, Lebleu B. A truncated HIV-1 Tat protein basic domain rapidly translocates through the plasma membrane and accumulates in the cell nucleus. J Biol Chem 1997; 272: 16010-7.

12. Perez F, Joliot A, Bloch-Gallego E, Zahraoui A, Triller A, Prochiantz A. Antennapedia homeobox as a signal for the cellular internalization and nuclear addressing of a small exogenous peptide. J Cell Sci 1992; 102: 717-22.

13. Schwarze SR, Ho A, Vocero-Akbani A, Dowdy SF. In vivo protein transduction: delivery of a biologically active protein into the mouse. Science 1999; 285: 1569-72.

14. Richard JP, Melikov K, Vives E, Ramos C, Verbeure B, Gait MJ, Chernomordik LV, Lebleu B. Cell-penetrating peptides-A reevaluation of the mechanism of cellular uptake. J Biol Chem 2003; 278: 585-90.

15. Gump JM, June RK, Dowdy SF. Revised role of glycosaminoglycans in TAT protein transduction domain-mediated cellular transduction. J Biol Chem 2010; 285: 1500-7.

16. Bertrand JR, Malvy C, Auguste T, Tóth GK, Kiss-Ivánkovits O, Illyés E, Hollósi M, Bottka S, Laczkó I. Synthesis and studies on cell-penetrating peptides. Bioconjug Chem 2009; 20: 1307-14.
17. Lundin P, Johansson H, Guterstam P, Holm T, Hansen M, Langel U, EL Andaloussi S. Distinct uptake routes of cell penetrating peptide conjugates. Bioconjug Chem 2008; 19: 253542.

18. Jiao CY, Delaroche D, Burlina F, Alves ID, Chassaing G, Sagan S. Translocation and endocytosis for cell-penetrating peptide internalization. J Biol Chem 2009; 284: 33957-65.

19. Vives E. Cellular uptake [correction of utake] of the Tat peptide: an endocytosis mechanism following ionic interactions. J Mol Recognit 2003; 16: 265-71.

20. Arnt CR, Chiorean MV, Heldebrant MP, Gores GJ, Kaufmann SH. Synthetic Smac/DIABLO peptides enhance the effects of chemotherapeutic agents by binding XIAP and cIAP1 in situ. J Biol Chem 2002; 277: 44236-43.

21. Kashiwagi H, McDunn JE, Goedegebuure PS, Gaffney MC, Chang K, Trinkaus K, Piwnica-Worms D, Hotchkiss RS, Hawkins WG. TAT-Bim induces extensive apoptosis in cancer cells. Ann Surg Oncol 2007; 14: 1763-71.

22. Watkins CL, Brennan P, Fegan C, Takayama K, Nakase I, Futaki S, Jones AT. Cellular uptake, distribution and cytotoxicity of the hydrophobic cell penetrating peptide sequence PFVYLI linked to the proapoptotic domain peptide PAD. J Control Release 2009; 140: 237-44.

23. Giorello L, Clerico L, Pescarolo MP, Vikhanskaya F, Salmona M, Colella G, Bruno S, Mancuso T, Bagnasco L, Russo P, Parodi S. Inhibition of cancer cell growth and c-Myc transcriptional activity by a c-Myc helix 1-type peptide fused to an internalization sequence. Cancer Res 1998; 58: 3654-9.

24. Mutoh M, Lung FD, Long YQ, Roller PP, Sikorski RS, O’Connor PM. A p21(Waf1/Cip1)carboxyl-terminal peptide exhibited cyclin-dependent kinase-inhibitory activity and cytotoxicity when introduced into human cells. Cancer Res 1999; 59: $3480-8$.

25. Fawell S, Seery J, Daikh Y, Moore C, Chen LL, Pepinsky B, Barsoum J. Tat-mediated delivery of heterologous proteins into cells. Proc Natl Acad Sci USA 1994; 91: 664-8.

26. Niesner U, Halin C, Lozzi L, Günthert M, Neri P, WunderliAllenspach H, Zardi L, Neri D. Quantitation of the tumortargeting properties of antibody fragments conjugated to cell-permeating HIV-1 TAT peptides. Bioconjug Chem 2002; 13: 729-36.

27. Duchardt F, Ruttekolk IR, Verdurmen WP, Lortat-Jacob H, Bürck J, Hufnagel H, Fischer R, van den Heuvel M, Löwik DW, Vuister GW, Ulrich A, de Waard M, Brock R. A cellpenetrating peptide derived from human lactoferrin with conformation-dependent uptake efficiency. J Biol Chem 2009; 284: 36099-108.

28. Kamide K, Nakakubo H, Uno S, Fukamizu A. Isolation of novel cell-penetrating peptides from a random peptide library using in vitro virus and their modifications. Int J Mol Med 2010; 25: $41-51$.

29. Rhee M, Davis P. Mechanism of uptake of C105Y, a novel cellpenetrating peptide. J Biol Chem 2006; 281: 1233-40.

30. Gao C, Mao S, Ditzel HJ, Farnaes L, Wirsching P, Lerner RA, Janda KD. A cell-penetrating peptide from a novel pVII-pIX phage-displayed random peptide library. Bioorg Med Chem 2002; 10: 4057-65.

31. Ward B, Seal BL, Brophy CM, Panitch A. Design of a bioactive cell-penetrating peptide: when a transduction domain does more than transduce. J Pept Sci 2009; 15: 668-74.

32. Pooga M, Hallbrink M, Zorko M, Langel U. Cell penetration by transportan. FASEB J 1998; 12: 67-77.

33. Chen Y, Shen Y, Guo X, Zhang C, Yang W, Ma M, Liu S, Zhang M, Wen LP. Transdermal protein delivery by a coad- 
ministered peptide identified via phage display. Nat Biotechnol 2006; 24: 455-60.

34. Rousselle C, Clair P, Lefauconnier JM, Kaczorek M, Scherrmann JM, Temsamani J. New advances in the transport of doxorubicin through the blood-brain barrier by a peptide vectormediated strategy. Mol Pharmacol 2000; 57: 679-86.

35. Morris MC, Depollier J, Mery J, Heitz F, Divita G. A peptide carrier for the delivery of biologically active proteins into mammalian cells. Nat Biotechnol 2001; 19: 1173-6.

36. Futaki S, Suzuki T, Ohashi W, Yagami T, Tanaka S, Ueda K, Sugiura Y. Arginine-rich peptides. An abundant source of membrane-permeable peptides having potential as carriers for intracellular protein delivery. J Biol Chem 2001; 276: 5836-40.

37. Soomets U, Lindgren M, Gallet X, Hällbrink M, Elmquist A, Balaspiri L, Zorko M, Pooga M, Brasseur R, Langel U. Deletion analogues of transportan. Biochim Biophys Acta 2000; 1467: 165-76.

38. Derossi D, Joliot AH, Chassaing G, Prochiantz A. The third helix of the Antennapedia homeodomain translocates through biological membranes. J Biol Chem 1994; 269: 10444-50.

39. Crombez L, Aldrian-Herrada G, Konate K, Nguyen QN, McMaster GK, Brasseur R, Heitz F, Divita G. A new potent secondary amphipathic cell-penetrating peptide for siRNA delivery into mammalian cells. Mol Ther 2009; 17: 95-103.

40. Elmquist A, Lindgren M, Bartfai T, Langel U. VE-cadherinderived cell-penetrating peptide, $\mathrm{pVEC}$, with carrier functions. Exp Cell Res 2001; 269: 237-44.

41. Saphire AC, Guan T, Schirmer EC, Nemerow GR, Gerace L. Nuclear import of adenovirus DNA in vitro involves the nuclear protein import pathway and hsc70. J Biol Chem 2000; 275: 4298-304.

42. Lopes LB, Flynn C, Komalavilas P, Panitch A, Brophy CM, Seal BL. Inhibition of HSP27 phosphorylation by a cell-permeant MAPKAP Kinase 2 inhibitor. Biochem Biophys Res Commun 2009; 382: 535-9.

43. Elliott G, O'Hare P. Intercellular trafficking and protein delivery by a herpesvirus structural protein. Cell 1997; 88: 223-33.

44. Zhang L, Torgerson TR, Liu XY, Timmons S, Colosia AD, Hawiger J, Tam JP. Preparation of functionally active cell-permeable peptides by single-step ligation of two peptide modules. Proc Natl Acad Sci USA 1998; 95: 9184-9.

45. Lin YZ, Yao SY, Veach RA, Torgerson TR, Hawiger J. Inhibition of nuclear translocation of transcription factor NF-kappa B by a synthetic peptide containing a cell membrane-permeable motif and nuclear localization sequence. J Biol Chem 1995; 270: $14255-8$.

46. Oehlke J, Krause E, Wiesner B, Beyermann M, Bienert M. Nonendocytic, amphipathicity dependent cellular uptake of helical model peptides. Protein Peptide Lett 1996; 3: 393-8.

47. Ho A, Schwarze SR, Mermelstein SJ, Waksman G, Dowdy SF. Synthetic protein transduction domains: enhanced transduction potential in vitro and in vivo. Cancer Res 2001; 61: 474-7.

48. Shen WC, Ryser HJ. Conjugation of poly-L-lysine to albumin and horseradish peroxidase: a novel method of enhancing the cellular uptake of proteins. Proc Natl Acad Sci USA 1978; 75: 1872-6.

49. Lang S, Rothen-Rutishauser B, Perriard JC, Schmidt MC, Merkle HP. Permeation and pathways of human calcitonin (hCT) across excised bovine nasal mucosa. Peptides 1998; 19: 599-607.

50. Schmidt MC, Rothen-Rutishauser B, Rist B, Beck-Sickinger A, Wunderli-Allenspach H, Rubas W, Sadée W, Merkle HP. Translocation of human calcitonin in respiratory nasal epithelium is associated with self-assembly in lipid membrane. Biochemistry 1998; 37: 16582-90.

51. Rennert R, Wespe C, Beck-Sickinger AG, Neundorf I. Developing novel hCT derived cell-penetrating peptides with improved metabolic stability. Biochim Biophys Acta 2006; 1758: 347-54.

52. Oehlke J, Krause E, Wiesner B, Beyermann M, Bienert M. Extensive cellular uptake into endothelial cells of an amphipathic beta-sheet forming peptide. FEBS Lett 1997; 415: 196-9.

53. Bong DT, Steinem C, Janshoff A, Johnson JE, Reza Ghadiri M. A highly membrane-active peptide in Flock House virus: implications for the mechanism of nodavirus infection. Chem Biol 1999; 6: 473-81.

54. Sadler K, Eom KD, Yang JL, Dimitrova Y, Tam JP. Translocating proline-rich peptides from the antimicrobial peptide bactenecin 7. Biochemistry 2002; 41: 14150-7.

55. De Coupade C, Fittipaldi A, Chagnas V, Michel M, Carlier S, Tasciotti E, Darmon A, Ravel D, Kearsey J, Giacca M, Cailler F. Novel human-derived cell-penetrating peptides for specific subcellular delivery of therapeutic biomolecules. Biochem J 2005; 390: 407-18.

56. Morris MC, Vidal P, Chaloin L, Heitz F, Divita G. A new peptide vector for efficient delivery of oligonucleotides into mammalian cells. Nucleic Acids Res 1997; 25: 2730-6.

57. El-Andaloussi S, Johansson HJ, Holm T, Langel U. A novel cell-penetrating peptide, M918, for efficient delivery of proteins and peptide nucleic acids. Mol Ther 2007; 15: 1820-6.

58. Lundberg P, El-Andaloussi S, Sutlu T, Johansson H, Langel U. Delivery of short interfering RNA using endosomolytic cellpenetrating peptides. FASEB J 2007; 21: 2664-71.

59. Mano M, Teodosio C, Paiva A, Simoes S, de Lima MCP. On the mechanisms of the internalization of S4(13)-PV cell-penetrating peptide. Biochem J 2005; 390: 603-12.

60. Fernandez-Carneado J, Kogan MJ, Castel S, Giralt E. Potential peptide carriers: amphipathic proline-rich peptides derived from the N-terminal domain of gamma-zein. Angew Chem Int Ed Engl 2004; 43: 1811-4.

61. Mueller J, Kretzschmar I, Volkmer R, Boisguerin P. Comparison of cellular uptake using 22 CPPs in 4 different cell lines. Bioconjug Chem 2008; 19: 2363-74.

62. Cameron A, Appel J, Houghten RA, Lindberg I. Polyarginines are potent furin inhibitors. J Biol Chem 2000; 275: 36741-9.

63. Horn M, Pavlik M, Doleckova L, Baudys M, Mares M. Arginine-based structures are specific inhibitors of cathepsin C. Application of peptide combinatorial libraries. Eur J Biochem 2000; 267: 3330-6.

64. Fugere M, Appel J, Houghten RA, Lindberg I, Day R. Short polybasic peptide sequences are potent inhibitors of PC5/6 and PC7: Use of positional scanning-synthetic peptide combinatorial libraries as a tool for the optimization of inhibitory sequences. Mol Pharmacol 2007; 71: 323-32.

65. Kloss A, Henklein P, Siele D, Schmolke M, Apcher S, Kuehn L, Sheppard PW, Dahlmann B. The cell-penetrating peptide octa-arginine is a potent inhibitor of proteasome activities. Eur J Pharm Biopharm 2009; 72: 219-25.

66. Kilk K, Mahlapuu R, Soomets U, Langel U. Analysis of in vitro toxicity of five cell-penetrating peptides by metabolic profiling. Toxicology 2009; 265: 87-95.

67. Kuo JH, Jan MS, Lin YL, Lin C. Interactions between octaarginine and U-937 human macrophages: global gene expression profiling, superoxide anion content, and cytokine production. J Control Release 2009; 139: 197-204. 
68. Delaroche D, Cantrelle FX, Subra F, Van Heijenoort C, Guittet E, Jiao CY, Blanchoin L, Chassaing G, Lavielle S, Auclair C, Sagan S. Cell-penetrating peptides with intracellular actinremodeling activity in malignant fibroblasts. J Biol Chem 2010; 285: 7712-21.

69. Moschos SA, Jones SW, Perry MM, Williams AE, Erjefalt JS, Turner JJ, Barnes PJ, Sproat BS, Gait MJ, Lindsay MA. Lung delivery studies using siRNA conjugated to TAT(48-60) and penetratin reveal peptide induced reduction in gene expression and induction of innate immunity. Bioconjug Chem 2007; 18: 1450-9.

70. Waldeck W, Pipkorn R, Korn B, Mueller G, Schick M, Tóth K, Wiessler M, Didinger B, Braun K. Transporter molecules influence the gene expression in HeLa cells. Int J Med Sci 2009; 6: 18-27.

71. Fotin-Mleczek M, Welte S, Mader O, Duchardt F, Fischer R,
Hufnagel H, Scheurich P, Brock R. Cationic cell-penetrating peptides interfere with TNF signalling by induction of TNF receptor internalization. J Cell Sci 2005; 118: 3339-51.

72. Hayess K, Benndorf R. Effect of protein kinase inhibitors on activity of mammalian small heat-shock protein (HSP25) kinase. Biochem Pharmacol 1997; 53: 1239-47.

73. Yamada T, Mehta RR, Lekmine F, Christov K, King ML, Majumdar D, Shilkaitis A, Green A, Bratescu L, Beattie CW, Das Gupta TK. A peptide fragment of azurin induces a p53mediated cell cycle arrest in human breast cancer cells. Mol Cancer Ther 2009; 8: 2947-58.

74. Dreiza CM, Brophy CM, Komalavilas P, Furnish EJ, Joshi L, Pallero MA, Murphy-Ullrich JE, von Rechenberg M, Ho YS, Richardson B, Xu N, Zhen Y, Peltier JM, Panitch A. Transducible heat shock protein 20 (HSP20) phosphopeptide alters cytoskeletal dynamics. FASEB J 2005; 19: 261-3. 